\title{
シェル構造体のフリーフォルム最適化手法*
}

\section{Free-Form Optimization Method for Shell Structures}

\author{
Masatoshi SHIMODA*1 \\ ${ }^{* 1}$ Toyota Technological Institute Dept. of Advanced Science and Technology \\ 2-12-1 Hisakata, Tempaku-ku, Nagoya, 468-8511 Japan
}

In this paper, a parameter-free optimization method is proposed for designing the optimal free-formed shell with an arbitrary surface. The compliance minimization problem of a linear elastic shell is dealt with here as an application example of this method. The optimum design problem is formulated as a distributed-parameter shape optimization problem under the assumptions that a shell is varied in the normal direction to the surface. The shape gradient function and the optimality conditions for this problem are theoretically derived by using the material derivative method and the Lagrange multiplier method. The shape gradient function is applied to the shell surface as a pseudo distributed force under a Robin condition for varying the surface, for minimizing the objective functional and for regularizing the mesh. With this approach, an optimal global and local curvature distribution of shell surface can be determined without any shape design parameterization. The validity and practical utility of this method are verified through several design problems. It is also confirmed that a membrane stress state is obtained by this method.

Key Words : Optimum Design, Shape Optimization, Shell, Bead Optimization, Traction Method, Free-Form

\section{1. 緒言}

シェル構造体はその薄さや軽量性, 加工性, 経済性等から, 建築, 土木構造から自動車, 航空機, 電車車両, 家電製品, 貯蔵タンク, 飲料容器, 樹脂トレイ等, 数多くの工業製品に利用されている他, 自然界にも数多く存 在する. その特長は力学的には主に膜応力と曲げ応力によって外力に抵抗することにあり, 幾何学的には曲率を 有していることにある. 薄さが招く低剛性や低強度は折り曲げや曲率設計, 閉断面化によって大きく改善される が，誤った設計は逆に低下を齊すため，適切な形状設計が極めて重要である．シェルの形状設計を行う場合の形 状変数としては面内方向，才なわち外部境界がシェル表面に沿いながらその法線方向（シェル表面に対しては接 線方向）へ変動する場合と面外方向，すなわちシェル表面が表面の法線方向へ変動する場合の二通りが考えられ る. 面内方向の最適化は初期曲率分布を保持しながら境界形状を最適化することができ, 特に設計の最終段階で の詳細形状の決定や軽量化，構造特性の改善に効果を発揮する，一方，面外方向の最適化ではシェルの曲面形状 が変更されるため, 面内方向の最適化に比較して飛躍的な構造特性の改善や軽量化が達成される. また，意匠デ ザインへ与える影響も大きいため, 設計自由度の大きい設計初期段階での適用が有効である. 著者らは両者の研 究を進め, 既報では初期形状の曲率分布を保ちながら板・シェルの最適境界形状を求める形状設計問題の解法を 提示した ${ }^{(1)}$. 本報では力学的に自然で滑らかな最適シェル形状を創成するため, 面外方向への形状变動を考え, 任意の曲率分布を有する最適自由曲面形状を求めるための手法を提示することを目的とする.

これまでのシェルの面外方向を設計変数と寸る形状最適化手法の研究では，他の連続体の形状最適化問題と同 様, 有限要素の節点の変動に伴う不適切メッシュ（jagged mesh problem）の平滑化 (mesh regularization, mesh smoothing） と大規模設計変数の扱いが問題であった. Zienkiewicz $ら^{(2)}$ による節点の直接変動で始まった有限要素

\footnotetext{
* 原稿受付 2012 年 9 月 25 日

*1 正員, 豊田工業大学 (厂468-8511 愛知県名古屋市天白区久方 2-12-1)

E-mail: shimoda@toyota-ti.ac.jp
} 
法との組み合わせによる連続体の形状最適化は前述の問題が顕在化した後 ${ }^{(3)}$, 設計変数の総数を変動させる節点 数より低減させる形状のパラメータ化（デザインエレメント法 ${ }^{(4)}$ とも呼ばれる）によって両問題を解決する方向 一向い, 後のシェルの形状最適化の研究も同様の方向へ向かった. 種々のパラメトリック手法が提案されている $か ゙^{(5)(6)}$, C ADベースと有限要素（F E ）ベース手法に大別される。CADベース手法 ${ }^{(3)}$ は自動メッシュや適当な メッシュの写像法との組み合わせが必要であり,ベーシスベクトル法 ${ }^{(7)(8)}$ に代表される F E ベース手法ではメッシ ユの歪みやメッシュの写像を考慮したパラメータ化が必要となる. 何らかのパラメータ化が成されれば数理計画 法に基づくべクトル空間の最適化手法により最適形状が求められる. その汎用性からパラメトリック手法は多く の汎用構造解析モジュールに実装されているが，得られる形状と特性のパラメータ依存性は避けられず，形状の 複雑化に伴い, パラメータの選択や設定が設計者を悩ましている.

本論文で対象とするシェルの面外方向の形状最適化問題に焦点を当てると，提案されてきた手法の大半はパラ メトリック手法に属する. シェル構造の有限要素解析ではメッシュの滑らかさが解析精度へ強く影響を与えるた め, メッシュの正則化を考慮した手法が特に要求される。軸対称シェルの半径のようなパラメータが容易な問題 への適用は多数行われている ${ }^{(9)}$. パラメータ化が難しい任意曲面に対しては少ない変数で滑らかな曲面を求める ため, Ramm ら ${ }^{(10)}$ はベジェ曲面, Rao $~^{(11)}$ はクーンズ曲面のコントロールポイントを設計変数とするパラメトリ ック手法を提案し, 屋根やドーム, ベル等に適用している. Uysal ら ${ }^{(12)}$ はデザインエレメント法をシェルの応力 問題に適用している. Ugail ら ${ }^{(13)}$ は PDE (Partial Differential Equation)法を用いてF Eベースの滑らかなシェル曲面 を求めている. いずれも形状の滑らかさは保持されるが, 得られる形状のパラメータ依存性は避けられず, 得ら れる構造特性も限定的となる. 複雑な形状をパラメトリック曲面で表現する場合, 曲面の分割や接合の問題も生 じる. パラメトリック手法で用いられる感度解析には離散化された剛性マトリックスに対して差分や半解析法が 用いられることが多い. 感度解析に限れば, 山崎 ${ }^{(14)}$ はアイソパラメトリック曲面シェル要素について直接微分法 に基づく形状感度を解析的に求めており, Taroco $5^{(15)}$ やLee $5^{(16)}$ は変分法に基づき, 形状感度を導出している.

著者らはこれまでパラメータ化を必要としない変分法に基づくノンパラメトリック形状最適化手法の研究を行 い, 3 次元連続体 ${ }^{(17)(18)}$ や前述のシェルの面内方向の形状最適化問題の解法を提示してきた. 手法は畔上により偏 微分方程式で支配される楕円型境界值問題の領域最適化の解法として提案された力法 ${ }^{(19)}\left(\mathrm{H}^{1}\right.$ 勾配法とも呼ばれ る）に基づいており，(1)滑らかさを保持（jaggedness free）しながら全節点の設計変数（大規模自由度）としての 変動が可能なこと（節点ベース手法ともいわれる），(2)パラメータ非依存性，(3)分布系（又は連続系）の感度を 導出するため, 剛性マトリックスの微分計算が不要（汎用F E M コードの利用が可能，（4)随伴変数法を利用す るため, 大規模設計変数の感度計算が効率的, といった主な特徴を有する. 本研究では同様の長所を継承しなが ら, 任意シェルの最適自由曲面形状を求めるための解法の開発を行う。任意曲率分布を有するシェル構造は局所 的な荷重分解と荷重伝達を可能とし, その最適化により理想とされる膜力伝達構造が得られることが期待される.

これまでの数少ないシェルのノンパラメトリック形状最適化の研究として, Bletzinger ${ }^{(20)}$ は全節点の形状変動 に対する感度を随伴変数法と半解析法で求め, jagging 問題を意図的なフィルタリングと面内の節点移動で解決す る手法を示している. Leiva ${ }^{(21)}$ は離散化された全節点の形状感度を半解析法により求め, ベーシスベクトル法によ って最適ビードパターンを求めているが，スムージング処理は行っていない. 下田ら ${ }^{(22)}$ も滑らかさを伴わず, 局 所的なビードの創成が可能な Leiva と同様な方法を示している. Choi $5^{(23)}$ はモノグラフの中で面内変動と剛体回 転でシェルの形状変動を定義し, シェルの面外方向変動に対する最適化方法を示している. Scherer ${ }^{(24)}$ は仮想エ ネルギー法と称した方法でメッシュの滑らかさを保つ方法を試みている. Mattheck ${ }^{(25)}$ は応力の大きさに応じて面 外の法線方向に節点を移動させる直感的な手法を示している．最適化手法を用いず，Isler の懸垂モデルによる形 状決定実験を模擬した手法も提案されている(26). いずれも本論文の目的とする力学的に自然で滑らかな最適曲面 を創成する手法とは言い難いようである.

以上を踏まえて本論文では任意形状のシェルを対象に, 最適な任意曲率分布を有する力学的に自然な自由曲面 形状を求めるための新たな手法を，剛性設計問題の 1 つである外力仕事（コンプライアンス）最小化問題を例に 提示する. 最適形状変動量は導出された感度関数（形状勾配関数と呼ばれる）を擬似外力としてロビン条件（弾 性支持）下で，シェル中央面に与えることにより，変位場として求める. 本手法に基づく数值解析により, 問題 に応じて滑らかな全体形状や局所的な曲率分布（ビード）が創成されることや得られた形状が膜力伝達構造とな ることも明らかにする。 
以下の章において，線形弾性シェルの支配方程式，及びコンプライアンス最小化問題の分布系形状最適化問題 としての定式化を示し，シェルの厚さ方向の仮想領域に対し，物質導関数法を適用することによって形状勾配関 数を導出する. 続いて, 具体的なフリーフォルム最適化手法について提示した後, 設計問題への適用により, 本 手法の有効性と実用性を示す. 更に, メッシュサイズや弾性支持の効果, 膜力伝達性についても数值実験を通し て検証する.

\section{2.ミシンドリン理論に基づくシェル構造の支配方程式}

図 1 のような有界な領域 $\Omega \subset \mathbb{R}^{3}$ を占め, 任意の曲率を有する線形弾性シェル構造を考える. 領域 $\Omega$ は中央面 $A$ と板厚方向の領域 $(-h / 2, h / 2)$ により, また, シェル端面 $S$ は $A$ の境界 $\partial A$ により次式のように定義する.

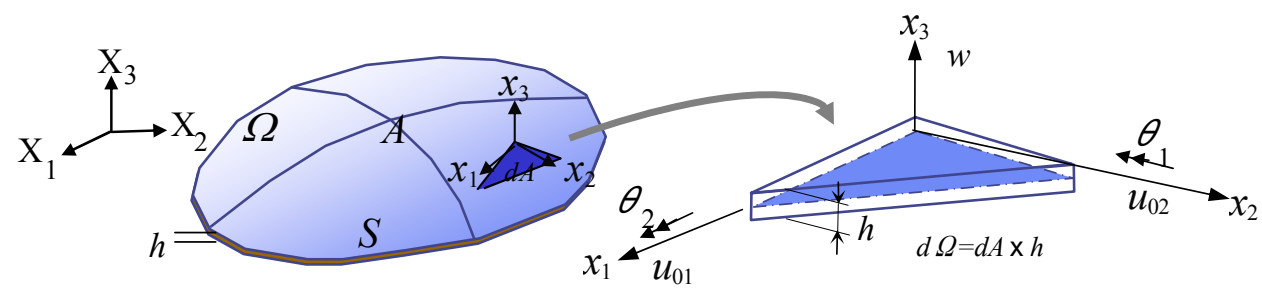

Fig. 1 Coordinate systems and DOF of shell

$$
\begin{aligned}
& \Omega=\left\{\left\{\left(x_{1}, x_{2}, x_{3}\right) \in \mathbb{R}^{3} \mid\left(x_{1}, x_{2}\right) \in A \subset \mathbb{R}^{2}, x_{3} \in\left(-\frac{h}{2}, \frac{h}{2}\right)\right\} .\right. \\
& \Omega=A \times\left(-\frac{h}{2}, \frac{h}{2}\right), \quad S=\partial A \times\left(-\frac{h}{2}, \frac{h}{2}\right) .
\end{aligned}
$$

このシェル構造の応力とひずみは板曲げ理論として Mindlin-Reissner 理論を用いて膜力成分との重ね合わせで評価される ものと仮定する. ただし, 膜力と曲げ力の連成は考慮しないこととする. また, 図 1 に示寸板の中心面の位置を与える局所 座標系 $\left(x_{1}, x_{2}, 0\right)$ から全体座標系 $\left(X_{1}, X_{2}, X_{3}\right) \sim 0$ 写像 $\varphi:\left(x_{1}, x_{2}, 0\right) \in \mathbb{R}^{3} \mapsto\left(X_{1}, X_{2}, X_{3}\right) \in \mathbb{R}^{3}$ は区分的に滑らかである と寸る. 局所座標系で表した変位 $\boldsymbol{u}=\left\{u_{i}\right\}_{i=1,2,3}$ は面内変位 $\left\{u_{\alpha}\right\}_{\alpha=1,2}$ と面外変位 $u_{3}$ に分けられ，次式のように表される.

$$
\begin{aligned}
& u_{\alpha}\left(x_{1}, x_{2}, x_{3}\right)=u_{0 \alpha}\left(x_{1}, x_{2}\right)-x_{3} \theta_{\alpha}\left(x_{1}, x_{2}\right), \\
& u_{3}\left(x_{1}, x_{2}, x_{3}\right)=w\left(x_{1}, x_{2}\right) .
\end{aligned}
$$

ここで， $\boldsymbol{u}_{0}=\left\{u_{0 \alpha}\right\}_{\alpha=1,2}, \quad \boldsymbol{w}, \boldsymbol{\theta}=\left\{\theta_{\alpha}\right\}_{\alpha=1,2}$ は図 1 に示寸座標系に従い，それぞれ板中心面の面内変位，面外変位 と回転角を表す．なお，ギリシャ文字の下添字は $\alpha=1,2$ を表すこととし，テンソルの添字表記においては総和規 約と空間座標に関する偏微分表記法 $(\cdot)_{r_{i}}=\partial(\cdot) / \partial x_{i}$ を使用する.

シェル構造の $\left(\boldsymbol{u}_{0}, w, \boldsymbol{\theta}\right) \in U$ に関する平衡方程式（弱形式）は 3 次元線形弾性体の平衡方程式の弱形式に式(4) と 式(5)の関係を代入し， $\sigma_{33}=0$ を考慮し， $\varepsilon_{33}$ を除くことにより式(6)から式(10)のように表される. また，板厚方 向の積分 $\left(\int_{\Omega}(\cdot) d \Omega=\int_{A} \int_{-h / 2}^{h / 2}(\cdot) d z d A\right)$ を行うことにより, 式(7)は式(9)のようにも表される. なお, 外力として, 領域 $A$ の部分領域 $A_{d}(\subset A)$ の部分領域 $A_{d_{1}}, A_{d_{2}}, A_{d_{3}}\left(\subset A_{d}\right)$ に零ではない単位面積当たりの荷重として, 面内荷重 $f=\left\{f_{\alpha}\right\}_{\alpha=1,2}$, 面外モーメント $m=\left\{m_{\alpha}\right\}_{\alpha=1,2}$, 面外荷重 $q$ が作用するとする. また, 領域全体に単位面積当たり $h \boldsymbol{b}=\left\{h b_{i}\right\}_{i=1,2,3}$ の物体力が作用するとする. 部分境界 $\partial A_{g}(\subset \partial A)$ の部分境界 $\partial A_{g_{1}}, \partial A_{g_{2}}, \partial A_{g_{3}}\left(\subset \partial A_{g}\right)$ には零でない単 位長さ当たりの荷重として, それぞれ面内力 $\boldsymbol{N}=\left\{N_{\alpha}\right\}_{\alpha=1,2}$, 曲げモーメント $\boldsymbol{M}=\left\{M_{\alpha}\right\}_{\alpha=1,2}$, せん断力 $Q$, が作用 するとする. 


$$
a\left(\left(\boldsymbol{u}_{0}, w, \boldsymbol{\theta}\right),\left(\overline{\boldsymbol{u}}_{0}, \bar{w}, \overline{\boldsymbol{\theta}}\right)\right)=l\left(\left(\overline{\boldsymbol{u}}_{0}, \bar{w}, \overline{\boldsymbol{\theta}}\right)\right), \quad \forall\left(\overline{\boldsymbol{u}}_{0}, \bar{w}, \overline{\boldsymbol{\theta}}\right) \in U
$$

ここで，内力に関する仮想仕事を表す（又は変分形式，弱形式）双一次形式 $a(\cdot, \cdot)$ と外力に関する仮想仕事を 表す一次形式 $l(\cdot)$ は式(7) 又式 (8)のように表される.（）は変分を表し, 許容関数空間 $U=\left\{\left(u_{01}, u_{02}, w, \theta_{1}, \theta_{2}\right) \in\left(H^{1}(A)\right)^{5}\right\}$ は変位の拘束条件を満たす 1 階の（5 次元）ソボレフ空間を表す.

$$
\begin{aligned}
& a\left(\left(\boldsymbol{u}_{0}, w, \boldsymbol{\theta}\right),\left(\overline{\boldsymbol{u}}_{0}, \bar{w}, \overline{\boldsymbol{\theta}}\right)\right)=\int_{\Omega}\left\{C_{\alpha \beta \gamma \delta}\left(u_{0 \alpha, \beta}-x_{3} \theta_{\alpha, \beta}\right)\left(\bar{u}_{0 \gamma, \delta}-x_{3} \bar{\theta}_{\gamma, \delta}\right)+C_{\alpha \beta}^{S} \gamma_{\alpha} \bar{\gamma}_{\beta}\right\} d \Omega \\
&=\int_{\Omega}\left\{C_{\alpha \beta \gamma \delta} \varepsilon_{\alpha \beta} \bar{\varepsilon}_{\gamma \delta}+C_{\alpha \beta}^{S} \gamma_{\alpha} \bar{\gamma}_{\beta}\right\} d \Omega \\
&\left(=\int_{A}\left\{c_{\alpha \beta \gamma \delta}^{B} \kappa_{\gamma \delta} \overline{\boldsymbol{\kappa}}_{\alpha \beta}+c_{\alpha \beta \gamma \delta}^{M} \varepsilon_{0 \gamma, \delta} \bar{\varepsilon}_{0 \alpha, \beta}+k c_{\alpha \beta}^{S} \gamma_{\alpha} \bar{\gamma}_{\beta}\right\} d A\right) . \\
& l\left(\left(\overline{\boldsymbol{u}}_{0}, \bar{w}, \overline{\boldsymbol{\theta}}\right)\right)=\int_{A_{d}}\left(f_{\alpha} \bar{u}_{0 \alpha}-m_{\alpha} \bar{\theta}_{\alpha}+q \bar{w}\right) d A+\int_{A} h\left(b_{\alpha} \bar{u}_{0 \alpha}+b_{3} \bar{w}\right) d A+\int_{\partial A_{g}}\left(N_{\alpha} \bar{u}_{0 \alpha} d s-M_{\alpha} \bar{\theta}_{\alpha}+Q \bar{w}\right) d s .
\end{aligned}
$$

ここで， $\left\{C_{\alpha \beta \gamma \delta}\right\}_{\alpha, \beta, \gamma, \delta=1,2},\left\{C_{\alpha \beta}^{S}\right\}_{\alpha, \beta=1,2}$ はそれぞれ対称性と正定值を有する膜力とせん断力に関する剛性テンソルを 表す. また, $\left\{c_{\alpha \beta \gamma \delta}^{B}\right\}_{\alpha, \beta, \gamma, \delta=1,2},\left\{c_{\alpha \beta}^{S}\right\}_{\alpha, \beta=1,2},\left\{c_{\alpha \beta \gamma \delta}^{M}\right\}_{\alpha, \beta, \gamma, \delta=1,2}$ はそれぞれ板厚方向の積分後の曲げ，せん断，膜力（平 面応力）に関する剛性テンソルを表す. $k$ はせん断補正係数を表す. また, $\left\{\varepsilon_{\alpha \beta}\right\}_{\alpha, \beta=1,2},\left\{\gamma_{\alpha}\right\}_{\alpha=1,2},\left\{\kappa_{\alpha \beta}\right\}_{\alpha, \beta=1,2}$, $\left\{\varepsilon_{0 \alpha \beta}\right\}_{\alpha, \beta=1,2}$ はそれぞれひずみテンソル, 横せん断ひずみテンソル, 曲率テンソル, 中立面でのひずみテンソルを 表し，それぞれ次式で定義される.

$$
\begin{array}{rlrl}
\varepsilon_{\alpha \beta} & \equiv \frac{1}{2}\left(u_{\alpha, \beta}+u_{\beta, \alpha}\right), & u_{\alpha, \beta}=u_{0 \alpha, \beta}-x_{3} \theta_{\alpha, \beta}, \quad \gamma_{\alpha}\left(=2 \varepsilon_{\alpha 3}\right) \equiv\left(w_{, \alpha}-\theta_{\alpha}\right), \\
\kappa_{\alpha \beta} \equiv \frac{1}{2}\left(\theta_{\alpha, \beta}+\theta_{\beta, \alpha}\right), & \varepsilon_{0 \alpha \beta} \equiv \frac{1}{2}\left(u_{0 \alpha, \beta}+u_{0 \beta, \alpha}\right) .
\end{array}
$$

板曲げ理論として Kirchhoff 理論（薄板）を用いる場合は $w_{, \alpha}=\theta_{\alpha}$ が仮定され，式(7)から式(9)における横せん断 ひずみに関わる項は除かれる. 式(6)を有限要素法で解く場合は局所座標系で求めた要素剛性マトリックスと要素 荷重ベクトルを全体座標系に正規直交変換し，重ね合わせる.

\section{3. 形状最適化問題と形状勾配関数の導出}

\section{$3 \cdot 1$ 自由曲面設計のための領域変動}

式(1)から式(3)で定義した初期領域 $\Omega$, 中央面 $A$, 境界 $\partial A$, 端面 $S$ の線形弾性シェル構造が図 2 のように央 面の面外方向（中央面に対して法線方向）の領域変動（設計速度場） $V$ にり領域 $\Omega_{s}$, 中央面 $A_{s}$, 境界 $\partial A_{s}$, 端 面 $S_{s}$ となるものと仮定する. また，領域変動に関して，領域は面内方向（中央面に対して接線方向）へは変動し ないこと, 及び板厚は不変であるとする。このとき $\Omega$ から $\Omega_{s}$ の領域変動は区分的に滑らかな写像 $T_{S}: X \in \Omega \mapsto \boldsymbol{X}_{s}(\boldsymbol{X}) \in \Omega_{s}, 0 \leq s \leq \varepsilon$ によって表される ${ }^{(19)(23)(27)}$. ここで， $\varepsilon$ は小さな整数， $(\cdot)_{s}$ は時間に相当する領

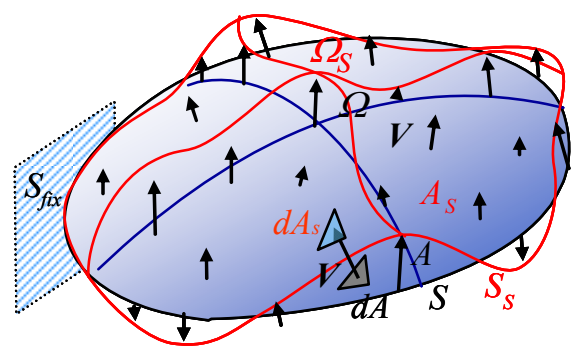

Fig. 2 Out-of-plane shape variation by $\boldsymbol{V}$ for free-form optimization of shell 
域の変動履歴を表す. $\boldsymbol{X}_{s}=T_{s}(\boldsymbol{X}), \Omega_{s}=T_{s}(\Omega)$ の関係を用いると, $s$ 回目の変動近傍での微小領域変動は次のよう に表される.

$$
T_{s+\Delta s}(\boldsymbol{X})=T_{s}(\boldsymbol{X})+\Delta s \boldsymbol{V}+O\left(|\Delta s|^{2}\right)
$$

ここで, 設計速度場 $\boldsymbol{V}\left(\boldsymbol{X}_{s}\right)=\partial T_{s}(\boldsymbol{X}) / \partial s$ は写像 $T_{s}(\boldsymbol{X})$ のオイラー導関数として与えられる. また, $O\left(|\Delta s|^{2}\right) \rightarrow 0(\Delta s \rightarrow 0)$ の関係を仮定する. 本論文で提案するシェルのフリーフォルム最適化手法（後述）はシェ ル中央面の最適な設計速度場 $\boldsymbol{V}\left(\boldsymbol{X}_{s}\right)$ を求める手法である.

本手法では形状感度, 寸なわち領域変動に対する評価汎関数の変動を物質導関数法 ${ }^{(23)}$ を利用して求める. 準備 として，用いる公式を以下に示す. まず，評価汎関数 $J$ が分布関数 $\phi_{s}$ の領域積分

$$
J=\int_{\Omega_{s}} \phi_{s} d \Omega
$$

で与えられるとき, 物質導関数 $\dot{J}$ は次の式で与えられる.

$$
\dot{J}=\int_{\Omega} \phi^{\prime} d \Omega+\int_{\Gamma} \phi V_{n} d \Gamma
$$

ここで, $V_{n}=n_{i} V_{i}$ を表し, ベクトル $\boldsymbol{n}$ (成分 $n_{i}$ ) はシェル中央面の外向き, 寸なわち局所座標系 $\left(x_{1}, x_{2}, x_{3}\right)$ に対す る $x_{3}$ 方向の単位法線ベクトルを表す。また， $(.)^{\prime}$ は $s$ の変動に対して空間座標に固定された分布関数の導関数 (形状導関数と呼ばれる ${ }^{(23)}$ ) を表し, 物質導関数と設計速度場 $\boldsymbol{V}$ とは $(\cdot)=(\cdot)^{\prime}+(\cdot)_{, i} V_{i}$ の式で関係付けられる. 次に，評価汎関数 $J$ が分布関数 $\phi_{s}$ の境界積分

$$
J=\int_{\Gamma_{s}} \phi_{s} d \Gamma
$$

で与えられるとき, 物質導関数 $\dot{J}$ は次の式で与えられる.

$$
\dot{J}=\int_{\Gamma}\left\{\phi^{\prime}+\left(\phi_{i} n_{i}+\phi H\right) V_{n}\right\} d \Gamma
$$

ここで, $H$ は $\Gamma$ が 3 次元の場合, シェル中央面 $A$ の平均曲率の 2 倍を表し, 2 次元の場合, $\partial A$ の曲率を表す.

\section{$3 \cdot 2$ コンプライアンス最小化問題（剛性最大化問題）}

体積および平衡方程式(6)を制約条件とし，コンプライアンス（外力仕事）を目的関数（最小化）とすると，シ ェル中央面の設計速度場 $\boldsymbol{V}$ を求める分布系の形状最適化問題は次のように表される.

$$
\begin{aligned}
\text { Given } & A, \hat{M}, \\
\text { find } & A_{s}(\text { or } \boldsymbol{V}), \\
\text { that minimizes } & l\left(\boldsymbol{u}_{0}, w, \boldsymbol{\theta}\right), \\
\text { subject to } & E q \cdot(6), \\
& M\left(=\int_{A} h d A\right) \leq \hat{M} .
\end{aligned}
$$

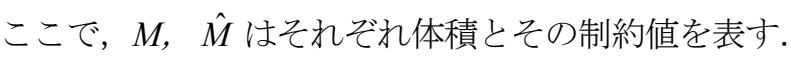

\section{$3 \cdot 3$ 形状勾配関数の導出}

この問題に対するラグランジュ汎関数 $L$ は $\left(\overline{\boldsymbol{u}}_{0}, \bar{w}, \overline{\boldsymbol{\theta}}\right)$ を状態方程式に対するラグランジュ乗数関数, $\Lambda$ を体積制 約に対するラグランジュ乗数として, 次のように表される. 


$$
L\left(\Omega,\left(\boldsymbol{u}_{0}, w, \boldsymbol{\theta}\right),\left(\overline{\boldsymbol{u}}_{0}, \bar{w}, \overline{\boldsymbol{\theta}}\right), \Lambda\right)=l\left(\boldsymbol{u}_{0}, w, \boldsymbol{\theta}\right)+l\left(\left(\overline{\boldsymbol{u}}_{0}, \bar{w}, \overline{\boldsymbol{\theta}}\right)\right)-a\left(\left(\boldsymbol{u}_{0}, w, \boldsymbol{\theta}\right),\left(\overline{\boldsymbol{u}}_{0}, \bar{w}, \overline{\boldsymbol{\theta}}\right)\right)+\Lambda(M-\hat{M}) .
$$

ラグランジュ汎関数 $L$ の領域変動に対する導関数 $\dot{L}$ は図 3 のように板厚方向に板厚分の仮想領域を考えながら, 領域 $\Omega$ から $\Omega_{s}$ へ変動に対して，中央面の設計速度場 $\boldsymbol{V}$ 用いて式(27)のように表される．ここで，シェル仮想 上面の外向き法線方向への変動を正とし， $\left(\boldsymbol{V} \cdot \boldsymbol{n}^{t o p}\right) \boldsymbol{n}^{t o p}=-\left(\boldsymbol{V} \cdot \boldsymbol{n}^{b t m}\right) \boldsymbol{n}^{b t m}$ の関係を仮定した. なお， $\boldsymbol{n}^{t o p}, \boldsymbol{n}^{b t m}$ は仮想 シェル上面と下面の外向きを正とする単位法線ベクトルを表し, 中央面の単位法線ベクトル $\boldsymbol{n}^{\mathrm{mid}}(\equiv \boldsymbol{n})$ との関係を $\boldsymbol{n}^{\text {mid }}(\equiv \boldsymbol{n})=\boldsymbol{n}^{\text {top }}=-\boldsymbol{n}^{b t m}$ とした. なお，材料は均質で領域変動に対して不変 $\left(\boldsymbol{C}^{\prime}=\dot{\boldsymbol{C}}=\mathbf{0}\right)$ であることを仮定した.

$$
\dot{L}=l\left(\boldsymbol{u}_{0}^{\prime}, w^{\prime}, \boldsymbol{\theta}^{\prime}\right)+l\left(\overline{\boldsymbol{u}}_{0}^{\prime}, \bar{w}^{\prime}, \overline{\boldsymbol{\theta}}^{\prime}\right)-a\left(\left(\boldsymbol{u}_{0}^{\prime}, w^{\prime}, \boldsymbol{\theta}^{\prime}\right),\left(\overline{\boldsymbol{u}}_{0}, \bar{w}, \overline{\boldsymbol{\theta}}\right)\right)-a\left(\left(\boldsymbol{u}_{0}, w, \boldsymbol{\theta}\right),\left(\overline{\boldsymbol{u}}_{0}^{\prime}, \bar{w}^{\prime}, \overline{\boldsymbol{\theta}}^{\prime}\right)\right)+\Lambda^{\prime}(M-\hat{M})+\langle G \boldsymbol{n}, \boldsymbol{V}\rangle, \boldsymbol{V} \in C_{\Theta}
$$

$$
\begin{aligned}
&\langle G \boldsymbol{n}, \boldsymbol{V}\rangle \equiv \int_{A} G \boldsymbol{n} \cdot V d A=\int_{A} G \boldsymbol{V}_{n} d A \\
&=\int_{A}\left[-\left\{C_{\alpha \beta \gamma \delta}\left(u_{0 \alpha, \beta}+\frac{h}{2} \theta_{\alpha, \beta}\right)\left(\bar{u}_{0 \gamma, \delta}+\frac{h}{2} \bar{\theta}_{\gamma, \delta}\right)-C_{\alpha \beta \gamma \delta}\left(u_{0 \alpha, \beta}-\frac{h}{2} \theta_{\alpha, \beta}\right)\left(\bar{u}_{0 \gamma, \delta}-\frac{h}{2} \bar{\theta}_{\gamma, \delta}\right)\right\}+h H A\right] \boldsymbol{V}_{n} d A \\
&+\int_{A_{d_{l}}}\left[f_{\alpha}^{\prime}\left(u_{0 \alpha}+\bar{u}_{0 \alpha}\right)+\left\{f_{\alpha, j} n_{j}\left(u_{0 \alpha}+\bar{u}_{0 \alpha}\right)+f_{\alpha}\left(u_{0 \alpha, j}+\bar{u}_{0 \alpha, j}\right) n_{j}+f_{\alpha}\left(u_{0 \alpha}+\bar{u}_{0 \alpha}\right) H\right\} \boldsymbol{V}_{n}\right] d A \\
&-\int_{A_{d}}\left[m_{\alpha}^{\prime}\left(\theta_{\alpha}+\bar{\theta}_{\alpha}\right)+\left\{m_{\alpha, j} n_{j}\left(\theta_{\alpha}+\bar{\theta}_{\alpha}\right)+m_{\alpha}\left(\theta_{\alpha, j}+\bar{\theta}_{\alpha, j}\right) n_{j}+m_{\alpha}\left(\theta_{\alpha}+\bar{\theta}_{\alpha}\right) H\right\} \boldsymbol{V}_{n}\right] d A \\
&+\int_{A_{d}}\left[q^{\prime}(w+\bar{w})+\left\{q_{, j} n_{j}(w+\bar{w})+q\left(w_{, j}+w_{, j}\right) n_{j}+q(w+\bar{w}) H\right\} \boldsymbol{V}_{n}\right] d A \\
&+\int_{A} h\left[b_{\alpha}^{\prime}\left(u_{0 \alpha}+\bar{u}_{0 \alpha}\right)+b_{3}^{\prime}(w+\bar{w})+\left\{b_{\alpha, j} n_{j}\left(u_{0 \alpha}+\bar{u}_{0 \alpha}\right)+b_{\alpha}\left(u_{0 \alpha, j}+\bar{u}_{0 \alpha, j}\right) n_{j}\right.\right. \\
&+\int_{\partial A_{g}}\left[N_{\alpha}^{\prime}\left(u_{0 \alpha}+\bar{u}_{0 \alpha}\right)+\left\{N_{\alpha, j} n_{j}\left(u_{0 \alpha}+\bar{u}_{0 \alpha}\right)+N_{\alpha}\left(u_{0 \alpha, j}+\bar{u}_{0 \alpha, j}\right) n_{j}+N_{\alpha}\left(u_{0 \alpha}+\bar{u}_{0 \alpha}\right) H\right\} \boldsymbol{V}_{n}\right] d S \\
&-\int_{\partial A_{g}}\left[M_{\alpha}^{\prime}\left(\theta_{\alpha}+\bar{\theta}_{\alpha}\right)+\left\{M_{\alpha, j} n_{j}\left(\theta_{\alpha}+\bar{\theta}_{\alpha}\right)+M_{\alpha}\left(\theta_{\alpha, j}+\bar{\theta}_{\alpha, j}\right) n_{j}+M_{\alpha}\left(\theta_{\alpha}+\bar{\theta}_{\alpha}\right) H\right\} \boldsymbol{V}_{n}\right] d S \\
&+\int_{\partial A_{g}}\left[Q^{\prime}\left(w+\bar{w}_{j}\right)+\left\{Q_{, j} n_{j}\left(w+\bar{w}_{3}\right)+Q\left(w_{, j}+\bar{w}_{, j}\right) n_{j}+Q(w+\bar{w}) H\right\} \boldsymbol{V}_{n}\right] d S
\end{aligned}
$$

ここで, $\boldsymbol{V}_{n}=V_{i} n_{i}$ を表し， $C_{\Theta}$ は領域変動の制約条件を満たす許容関数空間を表す.

この問題におけるラグランジュ汎関数の停留条件, すなわち, この問題の $\left(\boldsymbol{u}_{0}, w, \boldsymbol{\theta}\right),\left(\overline{\boldsymbol{u}_{0}}, \bar{w}, \overline{\boldsymbol{\theta}}\right)$ および $\Lambda$ に関する Kuhn-Tucker 最適性条件は次式で表される.

$$
\begin{aligned}
& a\left(\left(\boldsymbol{u}_{0}, w, \boldsymbol{\theta}\right),\left(\overline{\boldsymbol{u}}_{0}^{\prime}, \bar{w}^{\prime}, \overline{\boldsymbol{\theta}}^{\prime}\right)\right)=l\left(\left(\overline{\boldsymbol{u}}_{0}^{\prime}, \bar{w}^{\prime}, \overline{\boldsymbol{\theta}}^{\prime}\right)\right), \quad\left(\boldsymbol{u}_{0}, w, \boldsymbol{\theta}\right) \in U, \quad \forall\left(\overline{\boldsymbol{u}}_{0}^{\prime}, \bar{w}^{\prime}, \overline{\boldsymbol{\theta}}^{\prime}\right) \in U, \\
& a\left(\left(\boldsymbol{u}_{0}^{\prime}, w^{\prime}, \boldsymbol{\theta}^{\prime}\right),\left(\overline{\boldsymbol{u}}_{0}, \bar{w}, \overline{\boldsymbol{\theta}}\right)\right)=l\left(\left(\boldsymbol{u}_{0}^{\prime}, w^{\prime}, \boldsymbol{\theta}^{\prime}\right)\right), \quad\left(\overline{\boldsymbol{u}}_{0}, \bar{w}, \overline{\boldsymbol{\theta}}\right) \in U, \quad \forall\left(\boldsymbol{u}_{0}^{\prime}, w^{\prime}, \boldsymbol{\theta}^{\prime}\right) \in U,
\end{aligned}
$$

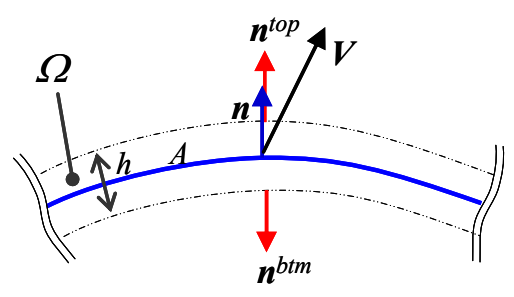

Fig. 3 Virtual domain in the thickness direction 


$$
\Lambda(M-\hat{M})=0, \quad \Lambda \geq 0, \quad M-\hat{M} \leq 0 .
$$

式(29)は式(7) と一致した状態変数 $\left(\boldsymbol{u}_{0}, w, \boldsymbol{\theta}\right)$ の支配方程式であり, 式 $(30)$ は随伴変数 $\left(\overline{\boldsymbol{u}}_{0}, \bar{w}, \overline{\boldsymbol{\theta}}\right)$ の支配方程式であ る. また，式(31)から式(33)は体積制約 $\Lambda$ に関する支配方程式である.これらの最適性条件が満たされているとす ると，式(27)は次式のようになる.

$$
\dot{L}=\langle G n, V\rangle \text {. }
$$

ここで, 式(28)における $\boldsymbol{V}$ の係数関数 $G \boldsymbol{n}(=\boldsymbol{G})$ は形状勾配関数と呼ばれる領域変動に対する形状感度関数を表 す.また，境界に作用寸る荷重 $\boldsymbol{N}, \boldsymbol{Q}, \boldsymbol{M}$ は物質固定で，それらが作用する部分境界は法線方向には変動しないこ と $\left(\boldsymbol{V}_{n}=0\right)$ ，及びシェル表面に作用寸る荷重 $f, m, q$ は領域変動に対し物質固定であること, 物体力 $h \boldsymbol{b}$ も物質固定 であることを仮定すると形状勾配関数は最終的に次式のように導出される. なお, 式(29)と式(30)の関係から来る この問題の自己随伴性，すなわち， $\left(\boldsymbol{u}_{0}, w, \boldsymbol{\theta}\right)=\left(\overline{\boldsymbol{u}}_{0}, \bar{w}, \overline{\boldsymbol{\theta}}\right)$ の関係を用いている.

$$
\begin{aligned}
\boldsymbol{G}=\left[-\left\{C_{\alpha \beta \gamma \delta}\left(u_{0 \alpha, \beta}+\frac{h}{2} \theta_{\alpha, \beta}\right)\left(u_{0 \gamma, \delta}+\frac{h}{2} \theta_{\gamma, \delta}\right)-C_{\alpha \beta \gamma \delta}\left(u_{0 \alpha, \beta}-\frac{h}{2} \theta_{\alpha, \beta}\right)\left(u_{0 \gamma, \delta}-\frac{h}{2} \theta_{\gamma, \delta}\right)\right\}+h H \Lambda\right. \\
\left.+2\left\{H f_{\alpha} u_{0 \alpha}-H m_{\alpha} \theta_{\alpha}+H q w+H h\left(b_{\alpha} u_{0 \alpha}+b_{3} w\right)\right\}\right] \boldsymbol{n} .
\end{aligned}
$$

導出されたシェル中央面に分布する形状勾配関数は次章で述べるフリーフォルム最適化手法において利用さ れる.

\section{4. シェルのフリーフォルム最適化手法}

1 章で述べたように，力法 (または $\mathrm{H}^{1}$ 勾配法) ${ }^{(19)}$ は畔上によってヒルベルト空間の勾配法に基づくノンパラ メトリック形状最適化手法として提案された. 負の形状勾配関数に比例した荷重をノイマン条件として設計境界 に作用させることにより，境界の滑らかさを保ちながら目的汎関数を減少させる設計速度場（領域変動量） $\boldsymbol{V} を$ 求める手法 (ノイマン型力法と呼ぶ) である ${ }^{(28)}$.メッシュスムージングの観点からは PDE 法 $^{(13)}$ と類似の側面も有 している. この設計速度場を求める解析を速度解析と呼ぶ，速度解析において，剛体運動を防ぐ目的も兼ね，設 計上の制約による形状拘束条件を与えているが，拘束の与え方や変動距離により要素の潰れや好ましくない変形 を生じる場合もある．特に，アスペクト比の大きい 2 次元や 3 次元の連続体の場合は好ましくない剛体的な変形 が生じ易く, 繰り返し計算での振動の発生等, 安定した収束に問題を生じる場合があり, これらの問題を改善す るため，畔上らにより弾性支持下で領域を変動させるロビン条件による力法（ロビン型力法と呼ぶ）も提案され ている ${ }^{(29)}$.

本論文が対象とするシェルの面外方向の形状最適化問題も類似の問題を潜在させており，ノイマン型力法では 剛体的な，あるいは全体的な変動が顕著に現れ，安定した収束の妨げとなることが推察される．例えば，周辺支 持された板に等分布荷重を与えて変動させた場合, 中央部の変位が最大となる変動が生じてしまう. そのため, シェルの最適自由曲面形状を求める方法として, ロビン型を基礎とし，ヒルベルト空間の勾配法で必要とされる 正定值テンソルとして対角成分に分布バネ定数 $\alpha(>0)$ を含むシェルの弾性テンソルを利用することとした. 剛性 マトリックスの対角成分を $\alpha$ で重み付けすることにより, 形状勾配関数の影響がそれ自身近傍に強く現れ, 不適 当な剛体的変動を抑えられることを狙っている. そのため, $\alpha$ を感度影響係数とも呼ぶ. 最適設計速度場 $\boldsymbol{V}$ は式 (35)の形状勾配関数の負值に比例した法線方向荷重を弾性支持状態のシェルの設計対象表面に与えることにより, 変位場として求められる，その概念図を図 4 に示寸. なお，設計や製造制約のための形状拘束が必要であれば付 加する. 本方法により理論的には無限自由度の自由曲面形状（任意曲率分布）が得られることから, この方法を シェルのフリーフォルム最適化手法と呼ぶことにする. 最適な設計速度場 $\boldsymbol{V}=\left(V_{0_{1}}, V_{0_{2}}, V_{3}\right)$ を求める支配方程式は 設計速度場 $\boldsymbol{V}=\left\{V_{i}\right\}_{i=1,2,3}$ を局所座標系における面内成分 $\boldsymbol{V}_{0}=\left\{V_{0_{\beta}}\right\}_{\beta=1,2}$ と面外成分 $V_{3}$ に分けて考えると, 式(36) のように表される。これは標準的な市販の有限要素法コードを利用して解くことができ，コードが MPC 


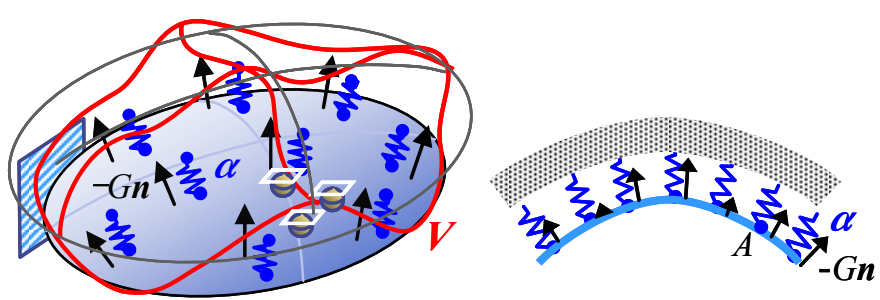

Fig. 4 Schematic of free-form optimization method for shell ( $\mathrm{H}^{1}$ gradient method for shell)

(Muli-points Constraint)や SPC (Single-point Constraint)，剛体要素，接触要素等の機能を有していれば，上述の形状 拘束のためにそれらを利用することも可能である.

$$
a\left(\left(\boldsymbol{V}_{0 \beta}, V_{3}, \boldsymbol{\theta}\right),\left(\overline{\boldsymbol{u}}_{0}, \bar{w}, \overline{\boldsymbol{\theta}}\right)\right)+\alpha\left\langle(\boldsymbol{V} \cdot \boldsymbol{n}) \boldsymbol{n},\left(\overline{\boldsymbol{u}}_{0}, \bar{w}, \overline{\boldsymbol{\theta}}\right)\right\rangle=-\left\langle G \boldsymbol{n},\left(\overline{\boldsymbol{u}}_{0}, \bar{w}, \overline{\boldsymbol{\theta}}\right)\right\rangle, \quad\left(\boldsymbol{V}_{0 \beta}, V_{3}, \boldsymbol{\theta}\right) \in C_{\Theta}, \quad \forall\left(\overline{\boldsymbol{u}}_{0}, \bar{w}, \overline{\boldsymbol{\theta}}\right) \in C_{\Theta},
$$

ここで， $C_{\Theta}$ は形状設計のための形状変動の拘束を満たした次式のような許容関数空間を表す.

$$
C_{\Theta}=\left\{\left(V_{0_{1}}, V_{0_{2}}, V_{3}, \theta_{1}, \theta_{2}\right) \in\left(H^{1}(A)\right)^{5} \mid\left(V_{0}, V_{3}, \boldsymbol{\theta}\right) \text { satisfy the constraints of shape variation on } S\right\} \text {. }
$$

ベクトル空間で定義された凸関数の勾配は正の最大傾斜の方向を示しており，正定值行列を利用して負の勾配 方向への微小移動を繰り返せば，最小值に向ってその関数は安定した収束を示寸. 関数空間においても同様で, 正定值テンソルを利用して負の感度関数に比例した変動を繰り返すことにより, 汎関数の最小化が達成される. 本手法においても以下のように確認される. 状態方程式と制約条件式が満たされているとき，ラグランジュ汎関 数 $L$ の摂動展開は次のように表すことができる.

$$
\Delta L=\langle G \boldsymbol{n}, \Delta s(\boldsymbol{V}, \boldsymbol{\theta})\rangle+O\left(|\Delta s|^{2}\right) .
$$

式(36)を式(38)に代入し，弾性テンソル $C_{\alpha \beta \gamma \delta}$ と $C_{\alpha \beta}^{S}$ の正定值性に基づく $a\left(\left(\boldsymbol{V}_{0 \alpha}, V_{3}, \boldsymbol{\theta}\right),\left(\overline{\boldsymbol{u}}_{0}, \overline{\boldsymbol{w}}, \overline{\boldsymbol{\theta}}\right)\right)$ と $\alpha\left\langle(\boldsymbol{V} \cdot \boldsymbol{n}) \boldsymbol{n},\left(\overline{\boldsymbol{u}}_{0}, \bar{w}, \overline{\boldsymbol{\theta}}\right)\right\rangle$ の正定值性を考慮すると, $\Delta s$ が十分小さいとき，次の関係が得られる.

$$
\Delta L=-a(\Delta s(\boldsymbol{V}, \boldsymbol{\theta}), \Delta s(\boldsymbol{V}, \boldsymbol{\theta}))-\alpha\langle(\Delta s \boldsymbol{V} \cdot \boldsymbol{n}) \boldsymbol{n}, \Delta s(\boldsymbol{V}, \boldsymbol{\theta})\rangle<0 .
$$

この関係は式(36)で決定された速度場 $\boldsymbol{V}$ を用いて領域を変動させることにより，凸性が保証されている問題に おいて，ラグランジュ汎関数 $L$ は必ず減少する関係を示している.

得られたシェル中央面の設計速度場を用いて領域を逐次更新することにより, 目的汎関数を減少させながら, 滑らかな収束形状が求められる. なお, 設計速度場の支配方程式(36)はバネ定数に対する応答問題になっており, 得られる設計速度場の大きさはバネ定数に依存するため, 繰り返しごとに規準化を行っている. 本手法の特徵を まとめると，(1)大規模自由度（理論上無限自由度）の形状設計が可能で, 目的汎関数を減少させる任意曲率分布 が求められる，(2)節点ベースで，形状のパラメータ化が不要である，(3)不適切メッシュ問題を回避した滑らかな 形状が得られる，(4)リメッシュが不要である，(5)市販の汎用F E Mコードを利用してシステムが容易に構築でき る. (6) (1), (3)及び(4)は弾性テンソルを介しての力による領域変動（速度解析）時に同時に実行される.

\section{5. 数值計算結果}


手法の有効性と実用性を検証するため，本手法を㨭り荷重を受ける長方形板問題，曲げ荷重を受けるU型ブラ ケット問題，及び一様圧力荷重を受ける球状シェル問題へ適用した．以下に計算結果と考察を示寸.

\section{$5 \cdot 1$ 㨭り荷重を受ける長方形問題}

図 5 (a)に示寸㧖り荷重を受ける長方形板（縦横サイズ $50 \times 100$, 板厚 $h=1$ ）について最適化解析を行った. 図 中の SPC:123 は自由度番号 1 ( $x$ 方向並進自由度), 2 ( $y$ 方向並進自由度), 3 ( $z$ 方向並進自由度 $)$ の単点拘束 を表す．速度解析では図 5 (b)のように周囲を単純支持し，体積制約值は初期形状の 1.05 倍とした。 なお，速度解 析でのバネ定数は $\alpha=20000$ とした. これは板の曲げ剛性 $D$ の約 1.2 倍に相当する. 初期形状と得られた最適形状 をそれぞれ図 6 (a) と図 6 (b)に示す. 本計算により滑らかさを有し，据り荷重に対して理想的なXX型のビードが 生成されていることが分かる。 このときの収束履歴を図 7 (a)に, 初期形状と最適形状での負荷に対するひずみ工 ネルギー成分の比較を図 7 (b)に示寸. なお, 図 6 (a)の体積とコンプライアンスは初期形状の值で規準化し, 図 7 (b)は初期形状のひずみエネルギーの曲げ成分で規準化している. 図 7 (a)から体積は制約を満たし，コンプライア ンスは安定的に収束し，初期形状に対し約 $90 \%$ 減少した高剛性形状が得られていることがわかる. 図 7 (b)から 初期形状の全ひずみエネルギーが曲げ成分から成るが, 最適形状では膜力成分が支配的になっており, 高剛性構

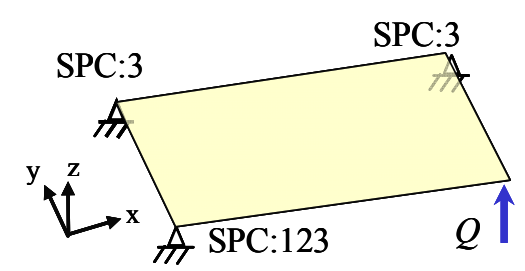

(a) Stiffness analysis

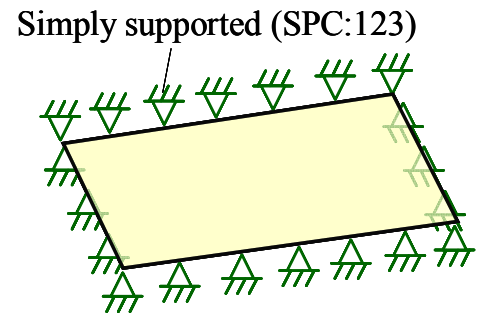

(b) Velocity analysis

Fig. 5 Boundary conditions for problem of rectangular plate under torsion

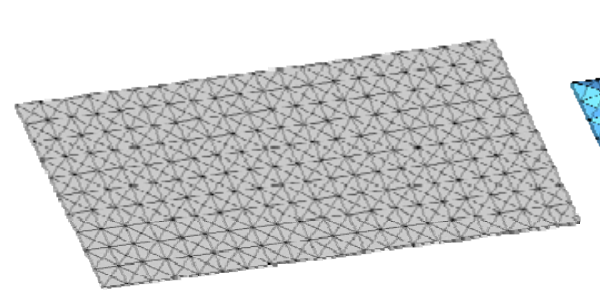

(a) Initial

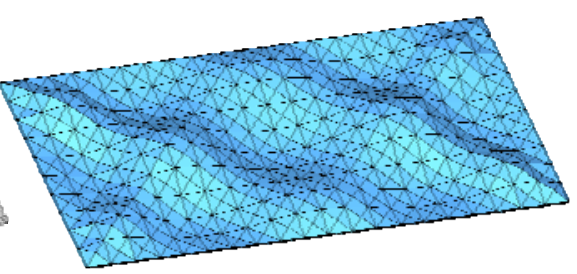

(b) Optimal

Fig. 6 Calculated result of rectangular plate under torsion

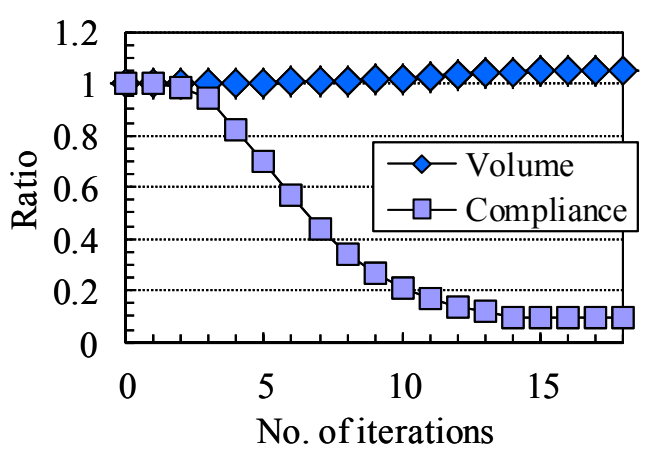

(a) Iteration histories

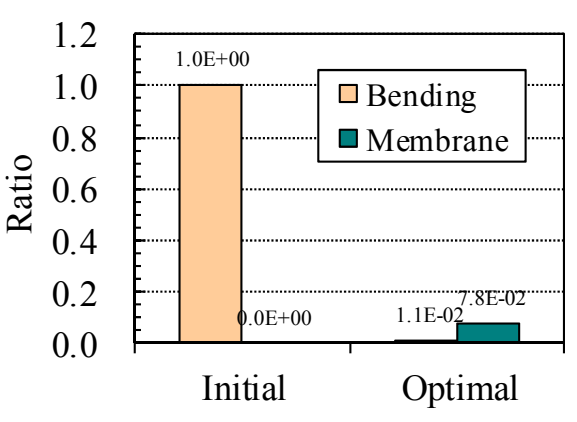

(b) Comparison of ratio of strain energy

Fig. 7 Calculated results of rectangular plate under torsion 
造の設計において理想的な膜力伝達構造が得られていることが分かる。これらの結果から本提案手法が良好に機 能していることが確認される.

\section{$5 \cdot 1 \cdot 1$ バネ定数の効果}

式(36)中のバネ定数 $\alpha$ と最適形状の関係を調べるため, $\alpha$ を $\alpha=0$ から $\alpha=1000000(=60 D)$ まで変化させながら数 值実験を行った。図8に得られた形状を，図 9 に初期形状の值で規準化したコンプライアンスの比較を示寸。ま た，比較のために，形状勾配関数の值を用いて節点座標を直接法線方向に変動させた結果（直接法）を図 $8(i)$ に 示す. 図8において, $\alpha$ が小さい $(a)$ や $(b)$ では中央部が盛り上がった形状となっているが, $\alpha=1.2 D$ 以上ではい ずれもXX型のビードが生成されていることがわかる.ただし, $(f)(g)(h)$ のような過大な $\alpha$ はビード部に jagging 問題(不適切メッシュによる波うち)を招いていることも確認される. 図 9 に示すコンプライアンスの比較結果か らも $\alpha=1.2 D$ から $\alpha=60 D$ に向かってコンプライアンスは増加し，直接法で最大となっていることが分かる. $\alpha=0$ から $\alpha=0.12 D$ のコンプライアンスは $\alpha=1.2 D$ より小さく局所解とも考えられるが，これらは形状勾配関数 による変動ではなく, 式(36)で得られる応答モードが支配的な形状であり, 求める最適形状とは区別すべきであ る. 別の幾つかの設計問題に $\alpha=1.2 D$ を適用し, 数值実験を行った結果, 本問題同様, 直接法による最終形状を 滑らかにした形状が得られ， $\alpha=1.2 D$ 程度の值であれば妥当な結果が得られることが分かった。

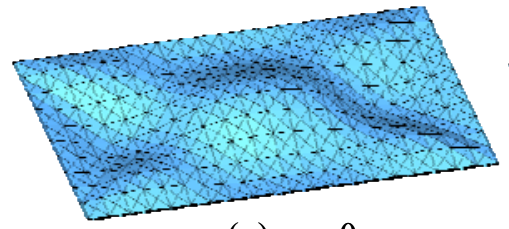

(a) $\alpha=0$

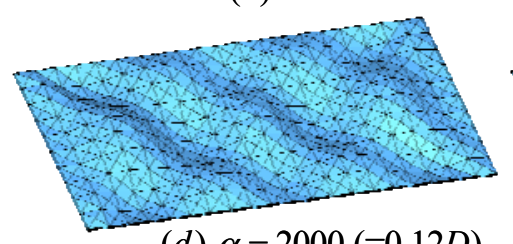

(d) $\alpha=2000(=0.12 D)$

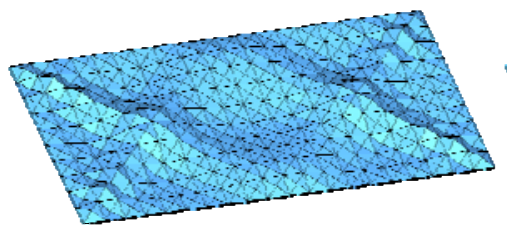

(g) $\alpha=500000(=30 D)$

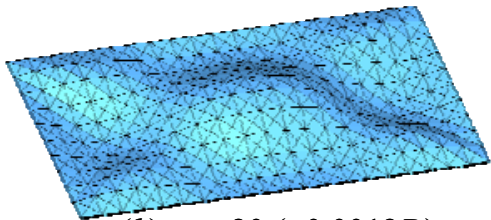

(b) $\alpha=20(=0.0012 D)$

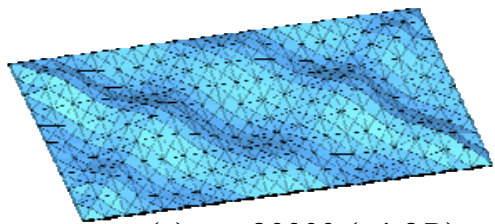

(e) $\alpha=20000(=1.2 D)$

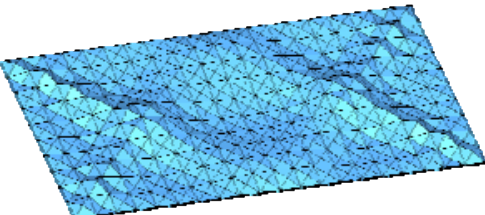

(h) $\alpha=1000000(=60 D)$

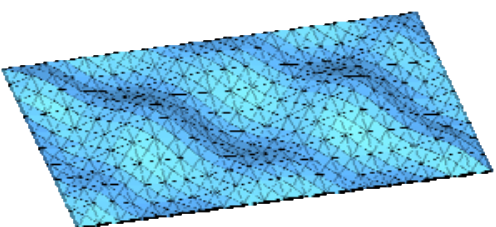

(c) $\alpha=200(=0.012 D)$

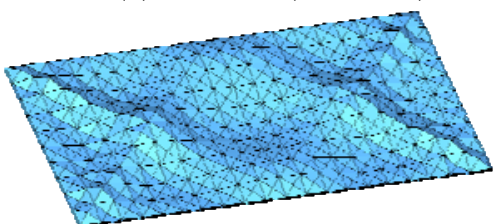

(f) $\alpha=200000(=12 D)$

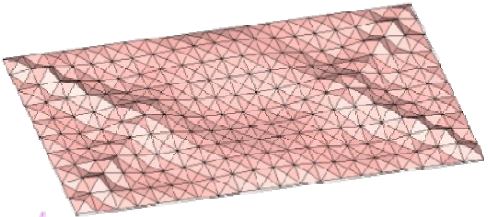

(i) Direct method

Fig. 8 Comparison of obtained shapes (vs. $\alpha$ )

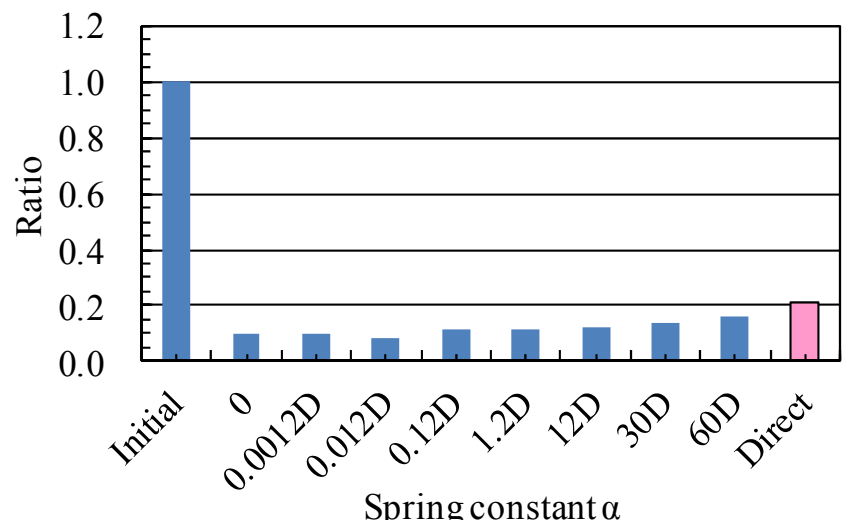

Fig. 9 Comparison of compliance (vs. $\alpha$ ) 


\section{$5 \cdot 1 \cdot 2$ メッシュ分割の影響}

メッシュ分割が最終形状に与える影響を調べるため，図 6 のモデルを含む 3 種類（200 要素，800 要素， 3200 要素）の異なる要素数のモデルを用い，図 5 と同様の条件で計算を行った. 得られた形状を図 10 に示寸が，メ ッシュ分割に依らず，XX型のビード形状が得られていること確認できる. また，要素数が増えるに従い，より 詳細な曲率分布が表現されていることも分かる.

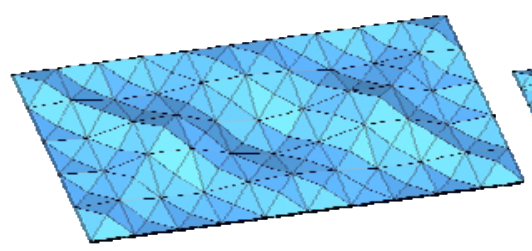

(a) 200 elements

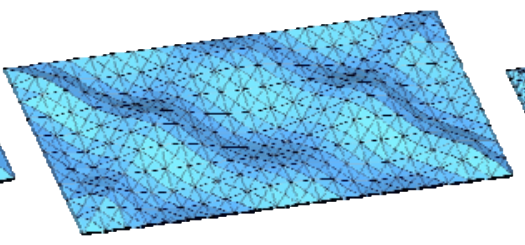

(b) 800 elements

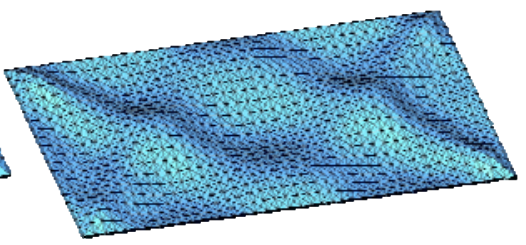

(c) 3200 elements

Fig. 10 Obtained shapes vs. No. of elements

\section{$5 \cdot 2$ 曲げ荷重を受けるU型ブラケット問題}

図 11 (a)のような内向きに等しい荷重が作用するU型ブラケット（板厚 $h=1$ ) について最適化解析を行った. 速度解析では図 11 (b)のように周囲を単純支持し, 体積制約は初期形状の 1.05 倍とした. なお, バネ定数は 5.1 節と同様， $\alpha=20000(=1.2 D)$ とした. 得られた形状を図 12 (a) に示す. 最大曲げモーメントを受ける曲がり部 にビードが形成され，断面 2 次モーメントを効率的に向上させた形状となっていることが分かる．また，体積と コンプライアンスの収束履歴（初期形状で規準化）を図 12 (b) に，ひずみエネルギー成分（曲げと膜力）の収束

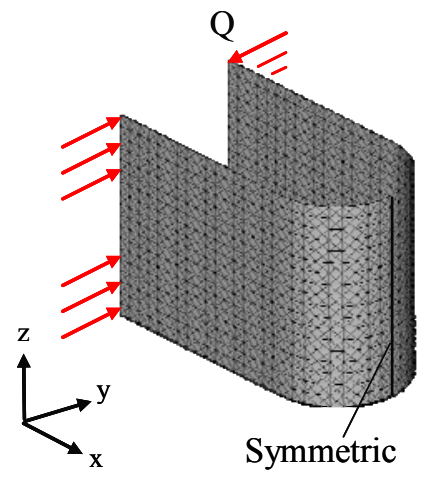

(a) Stiffness analysis

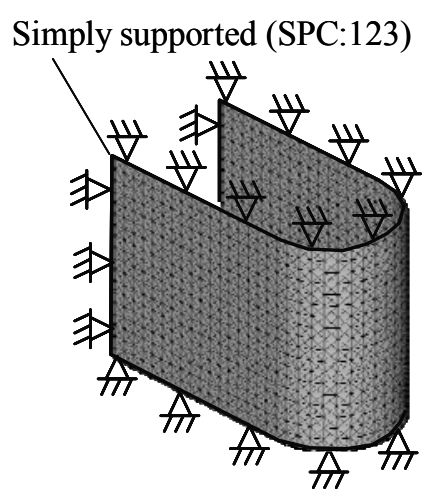

(b) Velocity analysis

Fig. 11 Boundary conditions for problem of U-shaped bracket

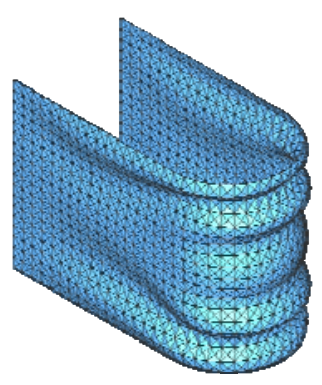

(a) Obtained shape

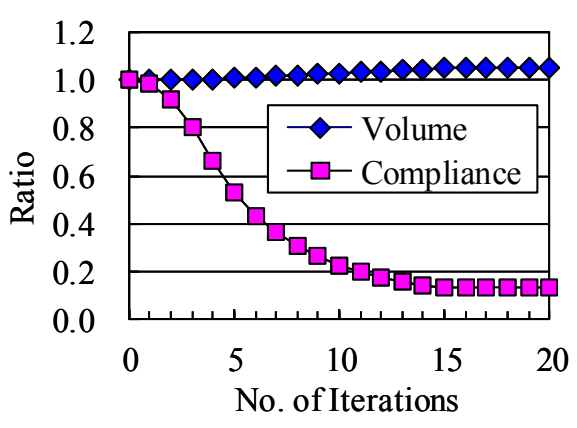

(b) Iteration histories of objective and constraint functionals

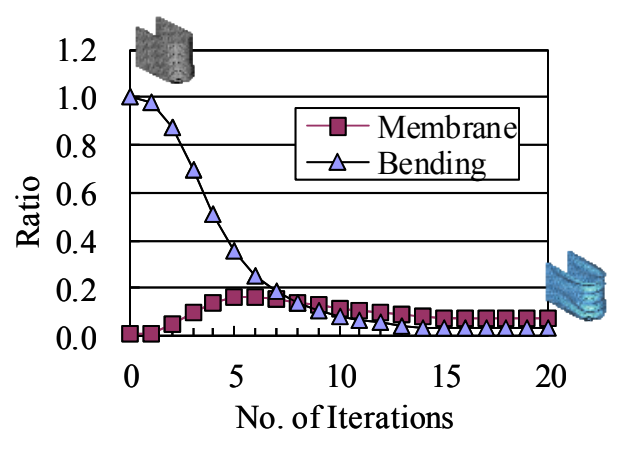

(c) Iteration histories of components of strain energy

Fig. 12 Calculated results of U-shaped bracket under bending 
履歴（初期形状の曲げ成分で規準化）を図 12 (c)に示す.コンプライアンスは安定した収束を示し，体積制約を 満たしながらコンプライアンスの減少率は約 $87 \%$ \%゙あった. 図 12 (c) において, 初期形状での全ひずみエネル ギーはほぼ曲げ成分からなり, 繰り返しが進むにつれて膜力成分が増加し, 最終的には膜力成分が支配的な膜力 伝達構造になっていることが分かる.

\section{$5 \cdot 3$ 球状シェル問題}

図 13 のように, 初期形状として意図的に凹凸を与えた球状シェルについて, 8 分の 1 対称モデルを切り出し, 外力として一様な圧力荷重を与えて最適化計算を行った. なお, 圧力は本来, 追従荷重のため非保存力であるが, 本論文では微小変形を仮定し, 要素の法線方向への一様荷重（保存力）として計算を行った. 体積一定の制約を 与え，凹凸を含む初期形状から滑らかな球面形状が得られるかの検証を目的とした. なお，速度解析（図 13 (b)) では周囲に単純支持の拘束を与え, バネ定数 $\alpha=20000(=1.2 D)$ とした. 初期形状と最適形状の比較を図 14 に 示す. 凹凸のある初期形状から, 狙い通り滑らかな球面形状へと最適化されていることが確認できる. このとき の収束履歴を図 15 (a)に示寸. 体積制約を満たしながらコンプライアンスは約８０％減少していることが分かる.

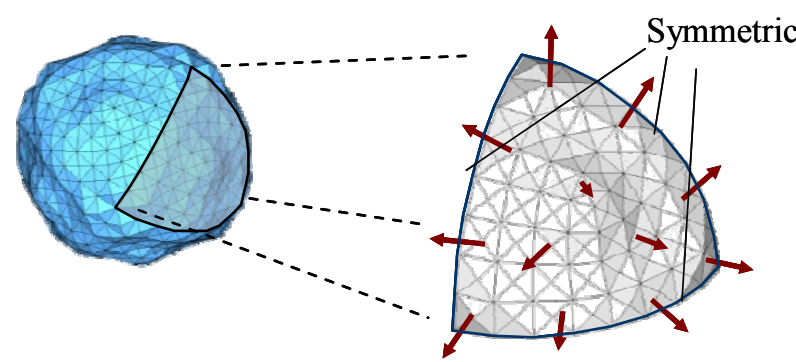

(a) Stiffness analysis

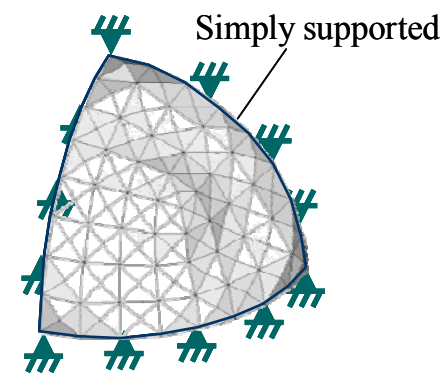

(b) Velocity analysis

Fig. 13 Boundary conditions for problem of spherical shell under uniform pressure

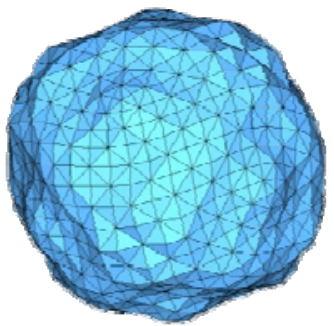

(a) Initial

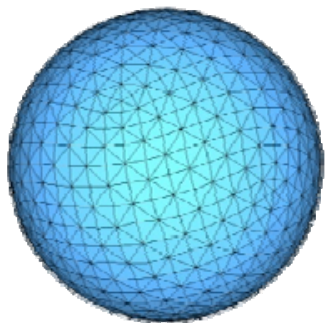

(b) Optimal

Fig. 14 Calculated result of spherical shell under uniform pressure

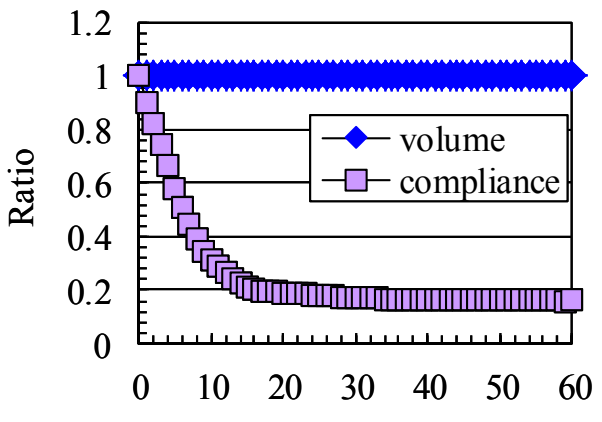

No. of iterations

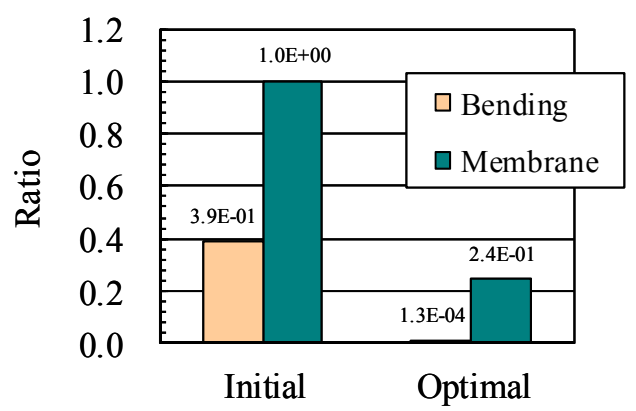

(b) Comparison of ratio of strain energy

(a) Iteration histories

Fig. 15 Calculated results of spherical shell under uniform pressure 
図 15 (b)に初期形状と最適形状のひずみエネルギー成分の比較（初期形状の曲げ成分で規準化）を示寸．初期形 状では曲げ成分と膜力成分の比が約 $1: 2.6$ であるが，最適化後は全ひずみエネルギーがほぼ膜力成分となり，理 想的な膜力伝達構造になっていることが分かる.

\section{6. 結言}

シェル構造の面外方向の変動を形状決定の変数とし, 力学的に最適な任意の自由曲面形状を求め得る形状最適 化手法（フリーフォーム最適化手法）を提示した。コンプライアンスを目的汎関数とする剛性設計問題を例に, 分布系の形状最適化問題として定式化し, 板厚方向の仮想領域に対して物質導関数の公式を適用することにより 形状勾配関数を理論的に導出した. 最適面外変動量の計算はロビン型力法を基礎とし, 関数空間の勾配法で必要 とされる正定值テンソルには対角成分を感度影響係数で重み付けしたシェルの岡性マトリックスを用いた. 本手 法により設計変数のパラメータ化を行わず，滑らかな任意自由曲面の創成を可能とし，シェルの形状最適化に潜 在する不適切メッシュ問題やパラメトリック手法が持つパラメータ依存性の問題, シェル問題に従来のノイマン 型力法を適用した際に発生する剛体的な変動の問題を同時に解決した. 本手法を基本的なシェルの形状設計問題 一適用した結果，力学的に自然な最適シェル形状が求められ，設定した設計問題の境界条件に応じて全体的な形 状や局所的なビード形状が生成されることを確認した. 更に, 得られた形状は構造体の高剛性化に必須の膜力伝 達となることも確認した.

\section{謝 辞}

本研究の一部には財団法人大幸財団の学術研究助成金を用いました．また，本研究の数值解析を元湘南工科大 学大学院生 (現コベルコクレーン(株) の岩佐恭平君と豊田工業大学大学院生の米倉正人君が遂行してくれました. 記して厚く感謝の意を表します。

\section{文献}

(1) 下田昌利, “板・シェル構造体の自由境界の形状設計のための最適化手法”, 日本機械学会論文集 A 編, Vol. 77, No. 782 (2011), pp. 1571-1582.

(2) O. C. Zienkiewicz, J. S. Campbell, "Shape optimization and sequential linear programming", Optimum Structural Design, R. Gallagher, O. C. Zienkiewicz (eds) (1973), pp. 109-126, Wiley: New York.

(3) Braibant, V. and Fleury, C., "Shape Optimal Design Using B-splines", Computer Methods in Applied Mechanics and Engineering, Vol. 44 (1984), pp. 247-267.

(4) Imam, M. H., “Three-dimensional Shape Optimization”, International Journal for Numerical Methods in Engineering, Vol. 18 (1982), pp. 661-673.

(5) Samareh, J. A., “A Survey of Shape Parameterization Techniques”, NASA Report CP-1999-209136 (1999), pp. 333-343.

(6) Choi, K. K. and Kim, N. H., Structural Sensitivity Analysis and Optimization 2 (2005), pp.620-651, Springer.

(7) Belegundu, A. D. and Rajan, S. D., "A Shape Optimization Approach Based on Natural Design Variables and Shape Functions”, Computer Methods in Applied Mechanics and Engineering, Vol. 66 (1988), pp. 87-106.

(8) Vanderplaats, G. N. and Miura H., "GENESIS-Structural Synthesis Software Using Advanced Approximation Techniques", AIAA Report 92-4839-CP (1992), pp. 180-190.

(9) 例えば, 大森博司, 山本健司, “応力分布を目的関数とする空間構造の形状最適化に関する研究 その 1 シェル構造 への適用”, 日本建築学会構造系論文集，No. 496 (1997), pp. 67-73.

(10) Ramm, U. E., Bletzinger, K. U. and Reitinger, R., "Shape Optimization of Shell Structures", Journal of the International Association for Shell and Spatial Structures, Vol. 34, No. 2 (1993), pp. 103-121.

(11) Rao, V. and Hinton, E., "Analysis and Optimization of Prismatic Plate and Shell Structures with Curved Planform - II. Shape Optimization”, Computers \& Structures, Vol. 52, No. 2 (1994), pp. 341-351.

(12) Uysal, M., Gul, R. and Uzman, U., "Optimum Shape Design of Shell Structures", Engineering Structures, vol.29 (2207), pp.80-87. 
(13) Ugail, H. and Wilson, M. J., "Efficient Shape Parameterization for Automatic Design Optimization Using a Partial Differential Equation Formulation”, Computers and Structures, Vol. 81 (2003), pp. 2601-2609.

(14) 山崎光悦, “アイソパラメトリック曲面シェル要素の設計感度解析法”, 日本機械学会論文集 A 編, Vol. 57, No. 537 (1991), pp. 1244-1251.

(15) Taroco, E. and Feijoo, R. A., "A Unified Approach for Shape Sensitivity Analysis of Elastic Shells", Structural and Multidisciplinary Optimization, Vol. 27 (2004), pp. 66-79.

(16) Lee, S. S. and Kwak, B. M., "Shape Sensitivity Analysis of Thin-Shell Structures", Finite Elements in Analysis and Design, Vol. 10 (1992), pp. 293-305.

(17) 下田昌利, 呉志強, 畔上秀幸, 桜井俊明, “汎用 FEM コードを利用した領域最適化問題の数值解法（力法によるアプ ローチ)”，日本機械学会論文集 A 編，Vol. 60, No. 578 (1994), pp. 2418-2425.

(18) Shimoda, M, Azegami, H. and Sakurai, T., "Traction Method Approach to Optimal Shape Design Problems", SAE 1997 Transactions, Journal of Passenger Cars, Section 6, Vol.106 (1998), pp. 2355-2365.

(19) 畔上秀幸, “領域最適化問題の一解法”, 日本機械学会論文集 A 編, Vol. 60, No. 574 (1994), pp. 1479-1486.

(20) Daoud, F., Firl, M. and Bletzinger, K. -U., "Filter Techniques in Shape Optimization with CAD-free Parameterization", Proceedings of $6^{\text {th }}$ World Congress of Structural and Multidisciplinary Optimization, (2005, Rio de Janeiro).

(21) Leiva, P. L., "Freeform Optimization: A New Capability to Perform Grid by Grid Shape Optimization of Structures", Proceedings of $6^{\text {th }}$ China-Japan-Korea Joint Symposium on Optimization of Structural and Mechanical Systems, (2010-6, Kyoto).

(22) 下田昌利, 中田佳宏, “ピラミッド型ベーシスベクトル法のシェルのビード設計問題への適用”, 日本機械学会設計工 学システム部門講演会講演論文集 (No. 10-27), 2105 (2010-10, 東京).

(23) Choi, K. K. and Kim, N. H., Structural Sensitivity Analysis and Optimization 1 (2005), Springer.

(24) Scherer, M., Denzer, R. and Steinmann, “A Fictitious Energy Approach for Shape Optimization, International Journal for Numerical Methods in Engineering, Vol. 82 (2010), pp. 269-302.

(25) Mattheck, C., Design in Nature (1998), pp.262-268, Springer-Verlag.

(26) Vizotto, I., "Computational Generation of Free-form Shells in Architectural Design and Civil Engineering", Automation in Construction, vol.19 (2010), pp.1087-1105.

(27) Sokolowski, J.and Zolesio, J.P., Introduction to Shape Optimization: Shape Sensivity Analysis (1991), Springer - Verlag.

(28) Azegami, H., Kaizu, S., Shimoda, M. and Katamine, E., "Irregularity of Shape Optimization Problems and an Improvement Technique", Computer Aided Optimum Design of Structures V, S. Hernandez and C. A. Brebbia (eds.) (1997), pp. 309-326, Computational Mechanics Publications.

(29) Azegami, H, Takeuchi, K., "A Smoothing Method for Shape Optimization: Traction Method Using the Robin Condition", International. Journal of Computational Methods, Vol. 3, No. 1 (2006), pp. 21-33. 